\title{
Neutrophil-Endothelial Cell Interactions on \\ Endothelial Monolayers Grown on Micropore Filters
}

\author{
Robert F. Taylor, Thomas H. Price, Stephen M. Schwartz, and \\ David C. Dale, The Puget Sound Blood Center, Seattle, Washington, 98104; \\ Departments of Medicine and Pathology, University of Washington, \\ Seattle, Washington, 98195
}

\begin{abstract}
A B S TRACT We have developed a technique for growing endothelial monolayers on micropore filters. These monolayers demonstrate confluence by phase and electron microscopy and provide a functional barrier to passage of radiolabeled albumin. Neutrophils readily penetrate the monolayer in response to chemotaxin, whereas there is little movement in the absence of chemotaxin. This system offers unique advantages over available chemotaxis assays and may have wider applications in the study of endothelial function.
\end{abstract}

\section{INTRODUCTION}

A vascular bed is a complex structure lined by a layer of endothelial cells. This lining prevent the uncontrolled leakage of soluble blood stream components while mediating the migration of leukocytes from the vascular bed into the tissues. There is increasing evidence that the endothelial cells play an active role in these events $(1,2)$.

Our earlier studies have examined the effect of inflammation and neutropenia on neutrophil margination and chemotaxis in vivo (3). These and other reports prompted our search for a method to study these processes in vitro. In an attempt to create a system which more closely mimics the intact vascular bed, we have developed a technique for measuring neutrophil migration through endothelial monolayers grown on polycarbonate filters. We believe this system offers unique advantages over presently available methods for studying neutrophil chemotaxis and vascular endothelial function.

\section{METHODS}

General reagents and supplies. Materials from the following sources were used: tissue culture media and reagents from Grand Island Biological Co., Grand Island, N. Y.; tissue culture flasks from Flow Laboratories, Inc., Rockville, Md.,

Received for publication 17 November 1980. and Corning Glass Works, Science Products Div., Corning, N. Y.; penicillin and streptomycin from E. R. Squibb \& Sons, Princeton, N. J., and Eli Lilly Co., Indianapolis, Ind.; polycarbonate filters from Nuclepore Corp., Pleasanton, Calif.; nitrocellulose filters from Millipore Corp., Bedford, Mass.; F-Met-Leu-Phe chemoattractant, Ficoll, and Cohn fraction V bovine serum albumin from Sigma Chemical Co., St. Louis, Mo.; USP gelatin (pork) from California Corp. for Biochemical Research, Los Angeles, Calif.; ${ }^{51} \mathrm{Cr}(200-500 \mu \mathrm{Ci} / \mathrm{g}$ as sodium chromate) and ${ }^{225}$ (in $0.1 \mathrm{M}$ sodium hydroxide) from New England Nuclear, Boston, Mass.; Hypaque from Winthrop Laboratories, New York. Cell counts were performed on a Coulter model ZBI (Coulter Electronics, Inc., Hialeah, Fla.). ${ }^{51} \mathrm{Cr}$ and ${ }^{125} \mathrm{I}$ activities were determined by automated gamma counter (Searle Analytic Inc., Div. of G. D. Searle \& Co., Des Plaines, Ill.).

Filter preparation. Before plating with endothelial cells, $25-\mathrm{mm}$ polycarbonate filters $(5-\mu \mathrm{m}$ pore size) were gelatin treated according to the method of Postlethwaite et al (4). Treated filters were stored in individual sealed envelopes.

Cell culture. Endothelial cells were prepared from bovine aortas using standard techniques (5) and grown in Waymouth's media with $10 \%$ fetal calf serum. Cultures thus obtained are morphologically pure and show positive immunofluorescence for Factor VIII (6). Subcultures from passages 5-12 were plated onto gelatin-prepared polycarbonate filters at a plating density of $8 \times 10^{5}$ cells/filter. The filters were incubated at $37^{\circ} \mathrm{C}, 100 \%$ humidity, and $5 \% \mathrm{CO}_{2}$ for $24 \mathrm{~h}$, then transferred to new plates where they grew to confluence (usually $2-3 \mathrm{~d}$ ). All monolayers were between 3 and $7 \mathrm{~d}$ postplating at the time of use.

Electron microscopy. Filters to be used for electron microscopy were placed in Karnofsky's fixative for a minimum of $1 \mathrm{~h}$, then transferred to $0.1 \mathrm{M}$ phosphate buffer $(\mathrm{pH} \mathrm{7.3)}$ for $24-48 \mathrm{~h}$. The filters were subsequently fixed in $1 \%$ osmium tetroxide in $0.1 \mathrm{M}$ phosphate buffer for $1.5 \mathrm{~h}$, dehydrated in graduated alcohols, and embedded in Epon. Sections were stained with uranyl acetate and lead citrate.

Neutrophil preparation. Heparinized blood was obtained from normal healthy donors. Neutrophils were isolated by Ficoll-Hypaque sedimentation and contaminating red cells removed by dextran sedimentation and hypotonic lysis $(7,8)$. The neutrophils were then suspended in modified Hank's balanced salt solution at a concentration of $20 \times 10^{6}$ polymorphonuclear leukocytes $/ \mathrm{ml}$.

Isolated neutrophils were labeled with ${ }^{51} \mathrm{Cr}\left(10 \mu \mathrm{Ci} / 10^{6}\right.$ polymorphonuclear leukocytes) using a modification of the Gallin et al. (9) method. Labeled cells were resuspended in medium 199 with $2 \%$ bovine serum albumin to a final 
concentration of $2 \times 10^{6}$ polymorphonuclear leukocytes $/ \mathrm{ml}$. A portion of the labeled cells was counted to determine specific radioactivity. In the final suspension, $96 \pm 2 \%$ of the ${ }^{51} \mathrm{Cr}$ was cell associated.

Neutrophil migration studies. Chemotaxis chambers were constructed for our laboratory from cast acrylic rods, which were carefully milled to create a modified blind well system. Upper and lower compartments were separated by two 25-mm filters and sealed with a silicone 0 ring. These chambers were thoroughly cleaned, dried, and warmed to $37^{\circ} \mathrm{C}$ before use. The chemoattractant for these studies, a $0.1 \mu \mathrm{M}$ solution of F-Met-Leu-Phe in medium 199 (10), was added to the lower compartment. This was covered with a $3-\mu \mathrm{m}$ nitrocellulose filter followed by a 5- $\mu \mathrm{m}$ polycarbonate filter. In studies using monolayers, the upper filter was a polycarbonte filter upon which a monolayer had been grown. All monolayers were washed in phosphate-buffered saline before use in the chambers.

To measure neutrophil migration, $1 \mathrm{ml}$ of ${ }^{51} \mathrm{Cr}$-labeled neutrophils $\left(2 \times 10^{6}\right.$ cells) was layered over the surface of the upper filter, and the chambers were incubated at $37^{\circ} \mathrm{C}$ at $100 \%$ humidity. After incubation, the fluid from both wells was aspirated, the lower by sampling through the filter with a small gauge needle, and the chambers carefully disassembled. Before counting, the nitrocellulose filter was rinsed-dipped twice in saline to dislodge any loosely adherent neutrophils.

For each experiment triplicate or quadruplicate filters were counted for $1 \mathrm{~min}$ in an automated gamma counter. Raw counts were corrected for relative radioactivity according to the standard equation: observed counts per minute $\times 10,000 /$ counts per minute $/ 10^{6}$ cells (9).

Albumin studies. Bovine serum albumin was labeled with ${ }^{125}$ I using the method of McConahey and Dixon (11), resulting in a solution in which $96 \%$ of the label was protein bound. This stock solution was diluted with $3 \%$ unlabeled bovine serum albumin in medium 199 to produce a radioactivity of $30,000-40,000 \mathrm{cpm} / \mathrm{ml}$.

The lower compartment of the chemotaxis chamber was filled with medium 199; the upper with $1 \mathrm{ml}$ of the diluted [ $\left.{ }^{125} \mathrm{I}\right]$ albumin solution. The compartments were separated by the standard two-filter system, with or without attached endothelial monolayer. Permeability of the filters to radioalbumin was expressed as counts per minute per milliliter in the lower well with all counts normalized to a standard radioactivity $(10,000 \mathrm{cpm})$ of the albumin solution in the upper compartment.

\section{RESULTS}

Endothelial monolayers could not be obtained when cells were plated on untreated filters. Confluent monolayers were demonstrated on gelatin-treated polycarbonate filters, usually within $2 \mathrm{~d}$ of plating. To assure uniformity on all filters, however, the monolayers were allowed to grow for a minimum of $3 \mathrm{~d}$ before use in the assay.

Cells on filters were examined by transmission electron microscopy to determine the continuity of the cell layer and the nature of the intercellular junctions. As seen on nonporous surfaces (6), the cultured cells had a typical endothelial appearance with features similar to those seen in endothelial cells in vivo. Large numbers of caveoli and vesicles were present at both

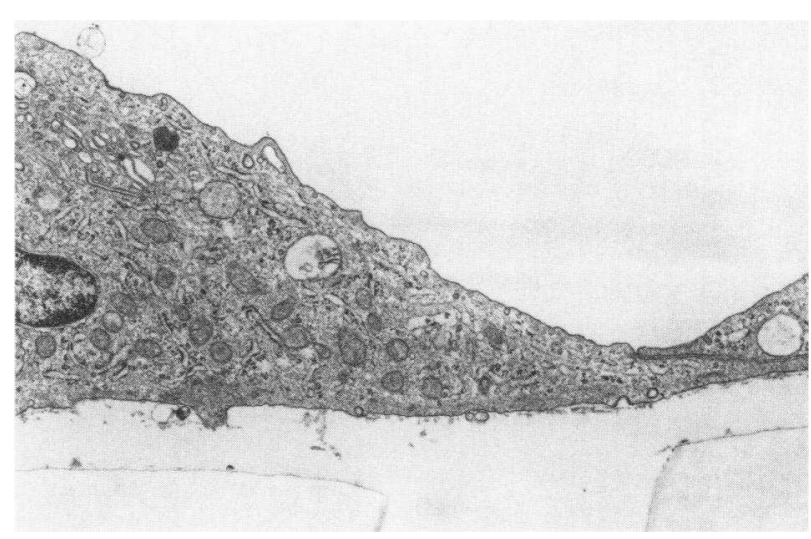

FIGURE 1 Transmission electron micrograph of endothelial cells on filter. Note the continuity of the cell layer over the filter pore and the presence of basement membrane-like material at the basal surface of the cells. $\times 5,500$

surfaces of the cell. The cell layers showed extensive regions of overlap at cell junctions, gap junctional complexes, and accumulation of cytoplasmic filaments along the basal cell membrane. Extracellular material with the appearance of basal lamina was seen on the basal cell surface, but never on the luminal surface. As shown in Figs. 1 and 2, the pores in the membrane were bridged by the continuous sheet of endothelial cells, although in some cases portions of the cytoplasm also extended down into the pore.

Studies of $\left[{ }^{125}\right.$ I] albumin permeability provided a functional evaluation of monolayer integrity. As shown in Fig. 3, albumin passage through the filter system without a monolayer showed a near linear increase throughout the incubation period. In studies with the

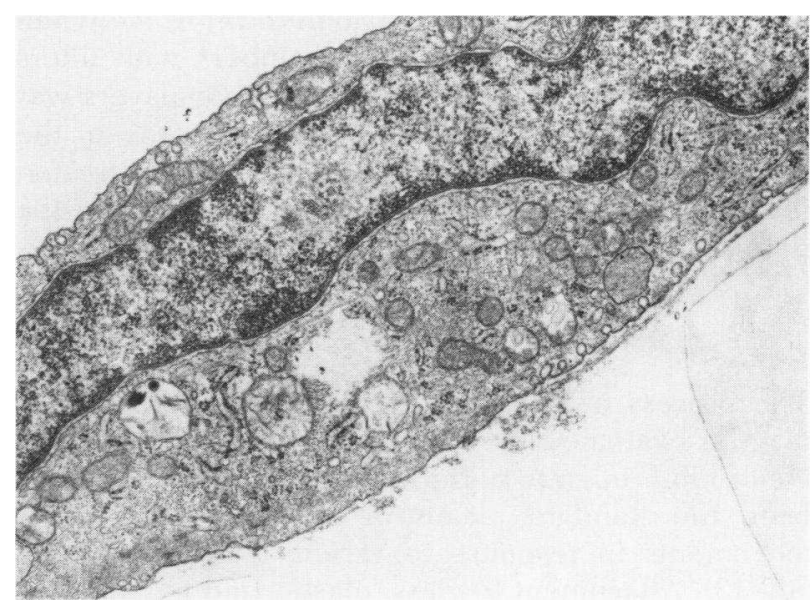

Figure 2 Transmission electron micrograph. Higher magnification of endothelial cell shows single cell-spanning pore in filter. $\times 9,500$ 


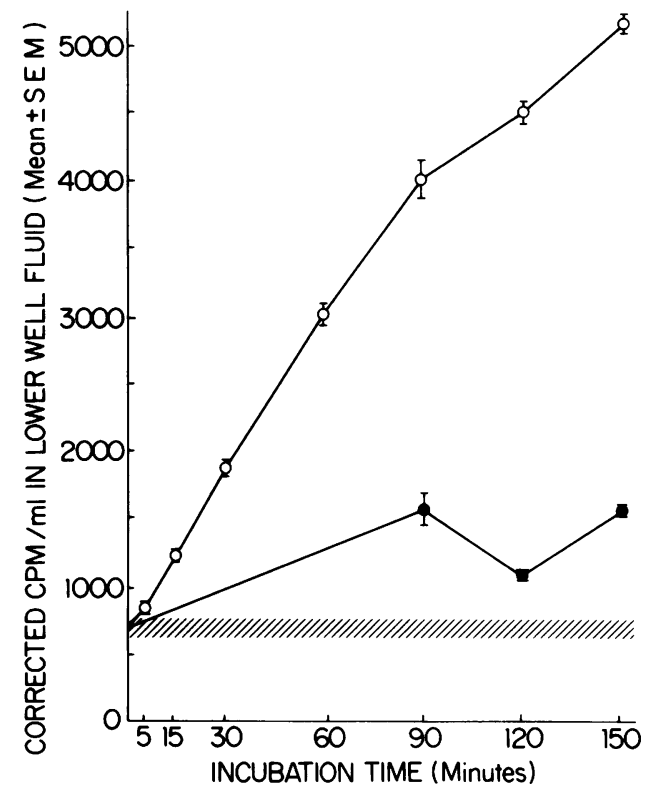

FIGURE 3 Endothelial monolayer permeability to [ $\left.{ }^{125} \mathrm{I}\right]-$ albumin. Figure depicts triplicate determinations of $\left.{ }^{[25} \mathrm{I}\right]$ albumin penetration into layer well of chemotaxis chamber. Shaded area represents background (or time 0) counts per minute \pm SEM. $\bigcirc$, without monolayer; 9 , with monolayer.

monolayer, the amount of labeled albumin appearing in the lower well represented $4.5 \%$ of the total label at $90 \mathrm{~min}$ and did not increase further throughout the period of incubation. In both experiments there was a background value of $500-800 \mathrm{cpm}$ that was presumably caused by leakage at the time of sampling the lower well.

Labeled neutrophils moved readily through the endothelium in response to the chemoattractant, whereas minimal migration occurred, even at $90 \mathrm{~min}$, when the chemoattractant was omitted (Fig. 4). When compared with the studies in chambers with filters alone, migration through endothelial monolayers was significantly lower $(P<0.01, t$ test $)$ both in the presence and absence of chemoattractant. Gel-treated filters without monolayers gave results similar to the untreated filters.

\section{DISCUSSION}

The process of neutrophil migration and adherence may be evaluated by a number of in vitro methods. Neutrophil migration through micropore filters has been the standard means of assessing granulocyte movements in response to various chemoattractants $(12,13)$. Attachment to glass, plastic, and nylon fibers have been used to simulate neutrophil interaction with vascular surfaces (14-16). Modifications of these techniques have been used to show changes in cell sur-

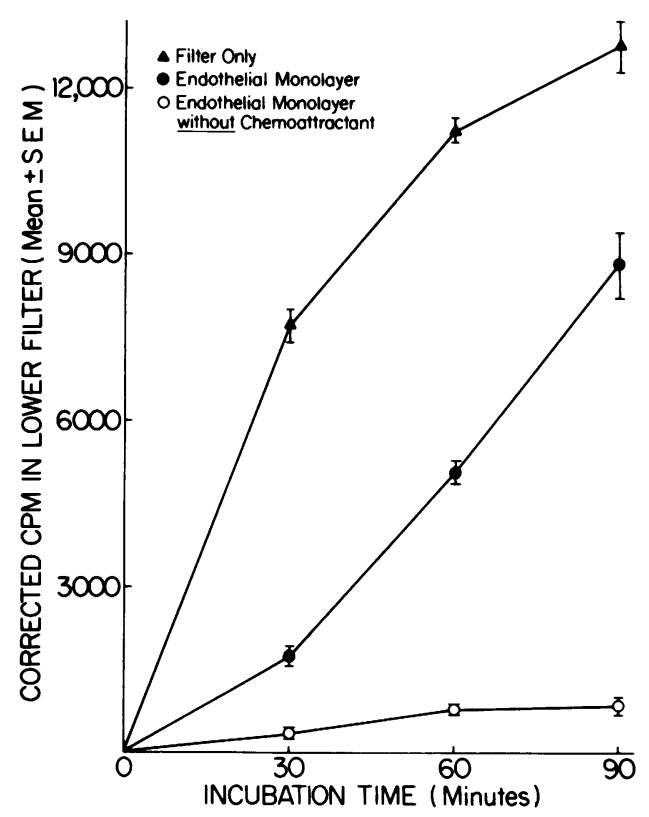

FiguRE 4 Neutrophil migration studies. Graph plots migration of ${ }^{51} \mathrm{Cr}$-labeled polymorphonuclear leukocytes into lower filter of chemotaxis chamber in response to F-Met-Leu-Phe chemoattractant (solid symbols). Bottom curve (open circles) shows minimal migration through endothelium in absence of chemoattractant.

face charge (17) and chemiluminescence (18) during chemotaxis in vitro.

Recently, cultured endothelial cells have been used to evaluate the process of neutrophil adherence $(16,19)$. Similar studies suggest that the endothelium secretes substances which directly influence adherence $(1,2)$. This apparent active role for the endothelium has made an understanding of neutrophil-endothelial cell interactions critical to the understanding of neutrophil adherence and migration in vivo. The standard adherence and chemotaxis assays have not provided a means to evaluate the entire process of neutrophil migration through a biologic barrier. Whereas migration through endothelial cells on plastic (20) and epithelial cells on filters (21) have been reported recently, no method is currently available for quantitatively evaluating the in vitro migration of neutrophils through endothelial cells.

We describe here a method for preparing endothelial monolayers on porous filters. These monolayers appear to be confluent by phase and electron microscopy, and by functional testing with ${ }^{125}$ I-labeled albumin. Our studies demonstrate that neutrophils will move through this monolayer in response to chemoattractants. Without such a stimulus, minimal migration occurs, even after $90 \mathrm{~min}$ of incubation.

The monolayer/filter system provides a means for simultaneously examining the effect of stimuli on 
neutrophil migration, adherence, and activation. Cultured endothelial cells are readily obtainable, grow to confluence in a relatively short time, and appear to perform in vivo synthetic functions (2). These characteristics make this technique a useful one for examining many aspects of endothelial cell function.

\section{ACKNOWLEDGMENTS}

The authors gratefully acknowledge the expert technical assistance of Mr. John Taylor and Mr. Stan Corpuz without whose help this work would not have been possible.

This work was supported in part by the Blood Research and Demonstration Center grant HL-17625 and National Institutes of Health grants HL-03174 and HL-18645.

\section{REFERENCES}

1. Thorgeirsson, G., and A. L. Robertson. 1979. The vascular endothelium-pathobiologic significance. Am. J. Pathol. 93: 803-847.

2. Boxer, L. A., J. M. Allen, and R. L. Baehner. 1980. Diminished polymorphonuclear leukocyte adherence. J. Clin. Invest. 66: 268-274.

3. Rosenshein, M. S., T. H. Price, and D. C. Dale. 1979. Neutropenia, inflammation, and the kinetics of transfused neutrophils in rabbits. J. Clin. Invest. 64: 580-585.

4. Postlethwaite, A. E., R. Snyderman, and A. H. Kang. 1976. The chemotactic attraction of human fibroblasts to a lymphocyte-derived factor. J. Exp. Med. 144: 1188-1203.

5. Gimbrone, M. A. 1976. Culture of vascular endothelium. Prog. Hemostasis Thromb. 3: 1-28.

6. Schwartz, S. M. 1978. Selection and characterization of bovine aortic endothelial cells. In Vitro (Rockville). 14: 966-980.

7. Price, T. H., and D. C. Dale. 1978. Neutrophil transfusion: effect of storage and of collection method on neutrophil blood kinetics. Blood. 51: 789-798.

8. DeChatelet, L. R., R. A. Migler, P. S. Shirley, H. B. Muss, P. Szejda, and D. A. Bass. 1978. Comparison of intracellular bacteriacidal activities of human neutrophils and eosinophils. Blood. 52: 609-617.
9. Gallin, J. I., R. A. Clark, and H. R. Kimball. 1973. Granulocyte chemotaxis: an improved in vitro assay employing ${ }^{51}$ Cr-labeled granulocytes. J. Immunol. 110: 233-240.

10. Showell, H. J., R. J. Freer, S. H. Zigmond, E. Schiffmann, S. Aswanikumar, B. Corcoran, and E. L. Becker. 1976. The structure-activity relations of synthetic peptides as chemotactic factors and inducers of lysosomal enzyme secretion for neutrophils. J. Exp. Med. 143: 1154-1169.

11. McConahey, P. J., and F. J. Dixon. 1966. A method of trace iodination of proteins for immunologic studies. Int. Arch. Allergy Appl. Immunol. 29: 185-189.

12. Boyden, S. V. 1962. The chemotactic effect of mixtures of antibody and antigen on polymorphonuclear leukocytes. J. Exp. Med. 115: 453-466.

13. Wilkinson, P. C., and R. B. Allan. 1978. Assay systems for measuring leukocyte locomotion: an overview. In Leukocyte Chemotaxis. J. I. Gallin and P. G. Quie, editors. Raven Press, New York. 1-24.

14. MacGregor, R. R., P. J. Spagnuolo, and A. L. Lentnek. 1974. Inhibition of granulocyte adherence by ethanol, prednisone, and aspirin, measured with an assay system. N. Engl. J. Med. 291: 642-645.

15. Fehr, J., and D. Clemens. 1979. Modulating influence of chemotactic factor-induced cell adhesiveness on granulocyte function. J. Clin. Invest. 64: 8-16.

16. Pearson, J. D., J. S. Carleton, J. E. Beesely, A. Hutchings and J. I. Gordon. 1979. Granulocyte adhesion to endothelium in culture. J. Cell Sci. 38: 225-235.

17. Gallin, J. I. 1980. Degranulating stimuli decrease the negative surface charge and increase the adhesiveness of human neutrophils. J. Clin. Invest. 65: 298-306.

18. Van Epps, D. E., and M. L. Garcia. 1980. Enhancement of neutrophila function as a result of prior exposure to chemotactic factor. J. Clin. Invest. 66: 167-175.

19. MacGregor, R. R., E. J. Macarak, and N. A. Kefalides. 1978. Comparative adherence to granulocytes fo endothelial monolayers and nylon fiber. J. Clin. Invest. 61: 697-702.

20. Beeseley, J. E., J. D. Pearson, A. Hutchings, J. S. Carleton, and J. L. Gordon. 1979. Granulocyte migration through endothelium in culture. J. Cell Sci. 38: 237-248.

21. Cramer, E. B., L. C. Milks, and G. K. Ojakian. 1980. Transepithelial migration of human neutrophils: an in vitro model system. Proc. Natl. Acad. Sci. U. S. A. 77: 4069-4073. 